\title{
Evaluation of Surgical Castration vs Immunocastration in Fattening Pigs
}

Pérez-Sato, Marcos ${ }^{1}$; Cruz-Cortés, Ariadna ${ }^{1}$; Castro-González, Numa Pompilio ${ }^{1}$; Valencia-Franco Edgar ${ }^{1}$; Pérez-Martínez, Jennifer²; Escobar-Hernández, Ramiro ${ }^{1}$; Soní-Guillermo, Eutiquio ${ }^{1 *}$

\begin{abstract}
${ }^{1}$ Benemérita Universidad Autónoma de Puebla. Ingeniería Agronómica y Zootecnia. Reforma 165, Tlatlauquitepec, Puebla, México. ²Benemérita Universidad Autónoma de Puebla. Ingeniería Agronómica y Zootecnia. Carretera Tecamachalco-Cañada Morelos km 7.5, El Salado, Tecamachalco, Puebla, México.
\end{abstract}

*Corresponding author: eutiquio.soni@acorreo.buap.mx

\section{ABSTRACT}

Objective: To determine the effect of surgical castration and immunocastration on productive parameters, carcass quality, as well as the physicochemical characteristics of the meat of fattening pigs.

Design/Metodology/Aproach: Ten male pigs of the York/Pietrain/Landrace breed with a body weight of $25 \pm 5 \mathrm{~kg}$ were used per treatment. They were housed in individual pens and fed diets according to their physiological state. The variables evaluated were analyzed with a student's t-test for independent samples.

Results: Results do not show differences $(p>0.05)$ in the productive variables, quality of the carcass or physicochemical characteristics.

Study Limitations/Implications: The study did not consider qualitative variables such as flavor and smell of the treatments. Findings/Conclusions: Immunocastration is an alternative to surgical castration since the quality of the carcass, the productive variables and the physicochemical characteristics of the meat are not affected, and it favors animal welfare.

Keywords: surgical castration, immunocastration, carcass quality, physicochemical characteristics.

\section{INTRODUCTION}

\section{The odor and taste}

of pork meat is caused primarily by the accumulation of androstenone and skatole in the fatty tissue, which is a significant quality problem of the carcass of complete males (Clarke et al., 2008). There are two castration alternatives to raise fattening pigs and thus avoid meat contamination, which are surgical castration and immunocastration (Batorek et al., 2012). Surgical castration of males before sexual maturity is carried out in many countries to avoid
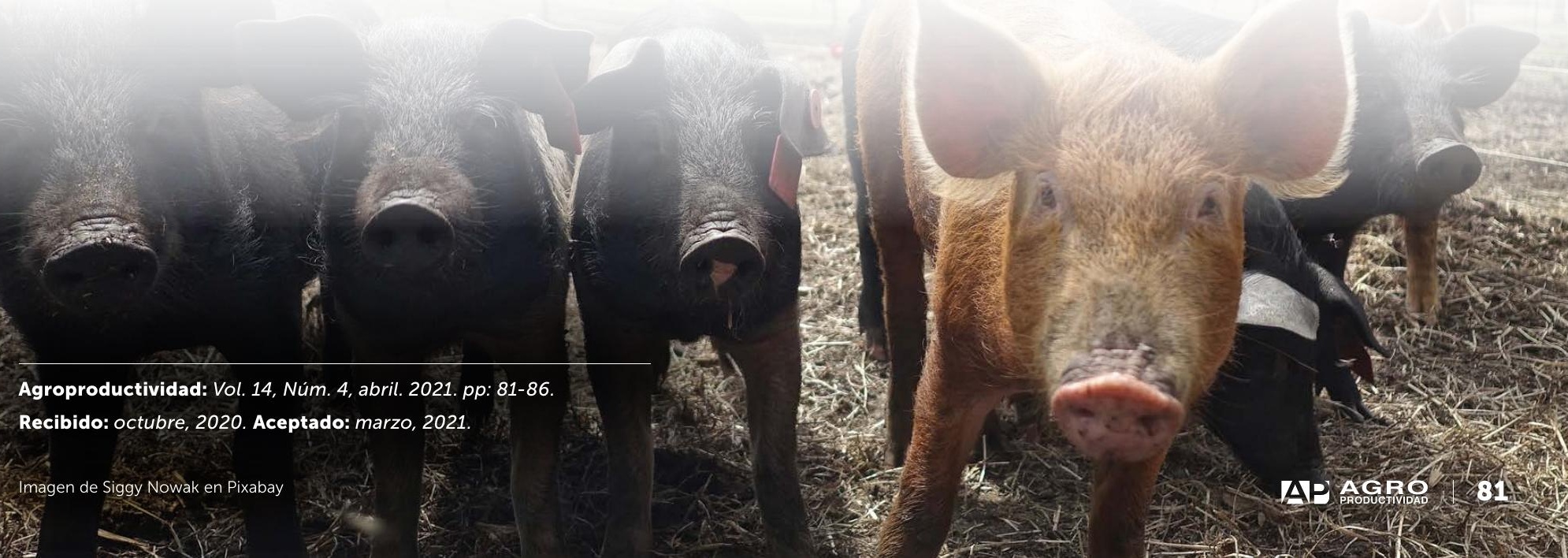
bad odor and bad flavor, increase the content of dorsal fat, and prevent stress in the farmyard. However, the preoccupation over animal welfare has increased and it necessary to resort to other castration practices (Fàbrega et al., 2010). The surgical castration of young pigs is associated to a higher mortality from complications such as infections and hernias; in addition, this practice is criticized since it is generally practiced without anesthesia, causing pain and a significant increase in the concentration of serum cortisol that indicates stress (McGlone et al., 1993; Clarke et al., 2008). However, immunocastration allows improving animal welfare in pork production, avoiding them suffering pain, in addition to increasing the profitability from growth to the finalization period, which is why this technique provides good meat quality (Dunshea et al., 2013). The objective of immunocastration is to deactivate testicular function through the neutralization of the hormone from the hypothalamus-pituitary-gonadal axis (GnRH) (Oonk et al., 1998). For the effectiveness of the GnRH vaccine, two applications are necessary: the first dose prepares the pig's immune system without altering the size or the function of the testicles, and the second dose stimulates the immunoprotection response that inhibits the function of the testicles (Font-i-Fornols et al., 2012). Because of this, the objective of this study was to determine the effect of surgical castration and immunocastration on productive parameters (average daily gain, daily feed intake and feed conversion ratio), carcass quality (backfat thickness, Longissimus dorsi mulcle área, percentage of lean meat), as well as the physicochemical characteristics of meat (water holding capacity, $\mathrm{pH}$ and color) in fattening pigs.
$1.8 \mathrm{~m})$ equipped with hopper type troughs and nipple drinking troughs. Food and water were offered as free access. The evaluation period lasted twelve weeks. The diets were formulated with the Solver command (Microsoft Excel, 2007), according to the requirements of the NRC (2012) for the three experimental stages (Table 1).

The technique of surgical castration was executed at 7 days of age: the piglet was restrained and the scrotum was washed with drinking water, then iodine was applied, and in the lower part of the scrotum an incision was made with a scalpel and at the same time the testicle was pressured to be extracted, and the other testicle was removed in the same way. Later, an antibiotic was applied via intramuscular and a cicatrizant on the wound, the latter during three days.

\section{MATERIALS AND METHODS}

The study was performed in a pig farm located in the municipality of Tulancingo de Bravo, Hidalgo, Mexico $\left(20^{\circ} 05^{\prime} \mathrm{N}, 98^{\circ} 22^{\prime} \mathrm{W}\right.$ and $2160 \mathrm{~m}$ of altitude). The climate is semi-dry temperate, with mean annual temperature of $14{ }^{\circ} \mathrm{C}$, and mean annual precipitation of 553 mm (INEGI, 2003).

The treatments were the following: T1 (surgically castrated males, SCM) and T2 (immunicastrated males, ICM); the study was divided into three experimental stages: 25-50, 50-75 and $75-100 \mathrm{~kg}$ of body weight (BW). The experimental units were 20 hybrid males (YorkxPietrain $\times$ Landrace) with average initial body weight (IBW) of $25 \pm 5 \mathrm{~kg}$, with ten pigs per treatment. The pigs were housed in individual pens (1.8X

\begin{tabular}{l|c|c|c}
\hline \multicolumn{1}{|c|}{ Table 1. Composition of diets. } \\
\hline \multicolumn{1}{|c|}{ Ingredients (\%) } & $25-50 \mathrm{~kg} \mathrm{BW}$ & $50-75 \mathrm{~kg} \mathrm{BW}$ & $75-100 \mathrm{~kg} \mathrm{BW}$ \\
\hline Sorghum & 75.06 & 77.80 & 84.53 \\
\hline Soybean meal & 19.70 & 17.13 & 11.90 \\
\hline Soybean oil & 2.20 & 2.25 & 0.92 \\
\hline Lysine $^{\text {A }}$ & 0.57 & 0.46 & 0.62 \\
\hline DL- Methionine & 0.14 & 0.15 & 0.20 \\
\hline L-Threonine & 0.26 & 0.15 & 0.20 \\
\hline Vitamins and minerals By C & 0.30 & 0.30 & 0.30 \\
\hline Salt & 0.20 & 0.25 & 0.30 \\
\hline Calcium carbonate & 1.31 & 0.92 & 0.55 \\
\hline Calcium orthophosphate & 0.56 & 0.89 & 0.75 \\
\hline Total & 100.00 & 10.00 & 100.00 \\
\hline
\end{tabular}

Nutritional Contribution (\%)

\begin{tabular}{l|r|c|c}
\hline Metabolic energy $\left(\mathrm{Mcal} \mathrm{kg}^{-1}\right)$ & 3.30 & 3.30 & 3.30 \\
\hline Crude Protein & 16.10 & 14.5 & 13.50 \\
\hline $\mathrm{Ca}$ & 0.66 & 0.59 & 0.64 \\
\hline $\mathrm{P}$ & 0.46 & 0.27 & 0.45 \\
\hline
\end{tabular}

ASupplied 50\% lysine. ${ }^{B}$ Supplied per kg of feed: vitamin A, 15,000 UI; vitamin D3, 2,500 UI: vitamin E, $37.5 \mathrm{Ul}$; vitamin K, $2.5 \mathrm{mg}$; thiamine, $2.25 \mathrm{mg}$; riboflavin, 6.25 ámg; niacin, 50 mg; pyridoxine, $2.5 \mathrm{mg}$; cyanocobalamin, $0.0375 \mathrm{mg}$; biotin, $0.13 \mathrm{mg}$; choline chloride, $563 \mathrm{mg}$; pantothenic acid, $20 \mathrm{mg}$; folic acid, $1.25 \mathrm{mg}$. CProvided per kg of feed: Fe, $150 \mathrm{mg}$; Zn, 150 mg; Mn, 150 mg; Cu, 10 mg; Se, 0.15 mg; l, 0.9 mg; Cr, 0.2 mg. T=Treatment. 
For immunocastration, two doses of the Improvac $^{\circledR}$ vaccine by Zoetis of $2 \mathrm{~mL}$ were applied via subcutaneous at the neck's base, immediately behind the right ear. This contains analogous protein conjugate from the gonadotropin liberation factor, the first at ten weeks of age and the second four weeks after the first dose.

Productive Variables: The variables evaluated in each stage were: daily weight gain (DWG); average daily feed intake (ADFI); feed conversión ratio (FCR). These variables were measured weekly.

Characteristics of the carcass: Backfat thickness (BT) and Longissimus dorsi muscle area (LMA) were measured at the beginning of the experiment and later at 50,75 and $100 \mathrm{~kg}$ of BW. Ultrasound equipment was used in real time (Landwind CU3OVET, Shenzhen, China), performing the measurement on the loin at the height of the tenth rib. Lean meat percentage (\%LM) was calculated with these data and those of Initial body weight (IBW) and final body weight (FBW), using the equation from the National Pork Producers Council (1991).

Physicochemical characteristics of the meat: These characteristics were evaluated at the end of the third experimental stage. When the pigs reached $100 \mathrm{~kg}$ of BW, five animals were slaughtered per treatment and samples were taken from the pigs' lumbar area to determine: $\mathrm{pH}$, color, and the water holding capacity (WHC). The slaughter was performed in the farm complying with the Official Mexican Norm NOM-033-SAG/ZOO-2014 (SEGOB, 2015).

The $\mathrm{pH}$ and the color were measured in the loin muscle $24 \mathrm{~h}$ post mortem. The $\mathrm{pH}$ was measured with a potentiometer (model pH1100), according to the measurement of pH in meat homogenates (Braña et al., 2011). The color measurements were performed with the help of a colorimeter (Hunter Lab, Chroma meter CR410, Konica Milolta Sesning, Inc., Japan) following the scale of the International Commission on Illumination (CIE) $L^{*} a^{*} b^{*}$, where $\left(L^{*}\right)=$ luminosity, $\left(a^{*}\right)=$ red-green index, and $\left(b^{\star}\right)=$ yellow-blue.

The WHC was determined in the samples according to the method proposed by Guerrero et al. (2002) at $24 \mathrm{~h}$ post mortem: $5 \mathrm{~g}$ of finely chopped meat were used, which were placed in tubes for centrifuge with $8 \mathrm{~mL}$ of $0.6 \mathrm{M}$ sodium chloride solution. Later, they were placed in ice during $30 \mathrm{~min}$, stirred in a vortex during $1 \mathrm{~min}$, and centrifuged for $15 \mathrm{~min}$ at 10,000 rpm. The supernatant was collected by decanting and measured in a test tube. The retained water volume is reported as the amount of water retained in $100 \mathrm{~g}$ of meat.

Statistical analysis: The variables evaluated were analyzed with a student's t- test for independent samples, which compares the means of two populations, with two treatments of 10 repetitions each, a degree of confidence of $95 \%$, and 0.05 degree of error, using the Statistical Analysis System software (SAS, 2010).

\section{RESULTS AND DISCUSSION}

\section{Productive Variables and Carcass Quality}

The productive variables DWG, ADFI and FCR in pigs of both treatments in the three stages evaluated were similar (Tables 2, 3 and 4) since they do not present differences $(P>0.05)$. These results differ from those of other studies, which reported that the best productive parameters (DWG and FCR) were for the ICM in comparison to those of SCM in animals of 71-115 kg BW (Fábrega et al., 2010; Fernandes et al., 2017; Grela et al., 2020).

Poulsen Nautrup et al. (2018) performed a meta-analysis of 78 studies where different parameters of SCM and ICM were compared and they found that the ICM had an increase in DWG (32.54 $\mathrm{g} \mathrm{day}^{-1}$ ) compared to the SCM; the FCR was lower during the entire period in the ICM, which resulted in $0.23 \mathrm{~kg}$ of ADFl less than $\mathrm{kg}$ of livestock weight; it was also found that the BW was approximately $2 \mathrm{~kg}$ higher in the $\mathrm{MCl}$ compared to the SCM.

However, in this study despite not showing differences ( $p>0.05$ ), the ICM had a lower DWG and higher index of FCR in the first period of evaluation (Table 2) and a better response in the productive characteristics compared with the SCM, in the stages of $50-75 \mathrm{~kg}$ and $75-100 \mathrm{~kg}$ (Table 3 and 4). The variation in the results from the different studies can be because of the age at which castration is done, since it can affect the growth rhythm of the animals and the higher growth of the muscular tissue as it approaches puberty (Quiles, 2005).

On the contrary, Morales et al. (2013) found that the ICM had a lower DWG compared to the SCM, and at the same time the ICM had a lower CAL $(P<0.001)$ than the SCM with 2.33 and $2.77 \mathrm{~kg} \mathrm{day}^{-1}$, respectively. Fàbrega et al. (2010) mention that this could be justified due to the stress that pigs suffer when being injected, and to an increase in body temperature. 
Table 2. Productive characteristics and carcass quality in male pigs with different castration techniques in the stage of $25-50 \mathrm{~kg} \mathrm{BW}$.

\begin{tabular}{|c|c|c|c|c|c|}
\hline \multirow{2}{*}{ Variable } & \multicolumn{2}{|c|}{ Surgical castration } & \multicolumn{2}{|c|}{ Immunocastration } & \multirow{2}{*}{$\mathrm{p}$ Value } \\
\hline & MNS & SD & MNS & SD & \\
\hline DWG $\left(k g d^{-1}\right)$ & 0.81 & 0.41 & 0.73 & 0.32 & 0.50 \\
\hline $\mathrm{DFI}\left(\mathrm{kg} \mathrm{d}^{-1}\right)$ & 1.66 & 0.65 & 1.62 & 0.57 & 0.84 \\
\hline $\mathrm{FC}(\mathrm{kg} / \mathrm{kg})$ & 2.22 & 0.62 & 2.26 & 0.60 & 0.84 \\
\hline $\mathrm{BT}(\mathrm{mm})$ & 4.66 & 1.29 & 2.56 & 0.91 & 0.16 \\
\hline LMA $\left(\mathrm{cm}^{2}\right)$ & 27.58 & 3.57 & 28.26 & 2.35 & 0.73 \\
\hline LM (\%) & 45.68 & 1.05 & 47.51 & 2.28 & 0.14 \\
\hline
\end{tabular}

$\operatorname{Pr}>|t|$ : values $<0.05$ are statistically different. MNS: mean; SD: standard deviation. DWG: daily weight gain; DFI: daily feed intake; FCR: feed conversion ratio; BT: backfat thickness; LMA: Longissimus dorsi muscle area; LM: lean meat

Table 3. Productive characteristics and carcass quality in male pigs with different castration techniques in the stage of $50-75 \mathrm{~kg} \mathrm{BW}$.

\begin{tabular}{|c|c|c|c|c|c|}
\hline \multirow{2}{*}{ Variable } & \multicolumn{2}{|c|}{ Surgical castration } & \multicolumn{2}{|c|}{ Immunocastration } & \multirow{2}{*}{ p Value } \\
\hline & MNS & SD & MNS & SD & \\
\hline DWG $\left(k g d^{-1}\right)$ & 0.74 & 0.46 & 0.80 & 0.15 & 0.68 \\
\hline $\mathrm{DFI}\left(\mathrm{kg} \mathrm{d}^{-1}\right)$ & 2.86 & 0.79 & 2.77 & 0.24 & 0.79 \\
\hline $\mathrm{FC}(\mathrm{kg} / \mathrm{kg})$ & 4.08 & 1.17 & 3.73 & 0.43 & 0.51 \\
\hline $\mathrm{BT}(\mathrm{mm})$ & 6.24 & 1.51 & 6.18 & 0.26 & 0.94 \\
\hline LMA $\left(\mathrm{cm}^{2}\right)$ & 32.38 & 2.58 & 32.52 & 0.67 & 0.92 \\
\hline LM (\%) & 42.18 & 1.24 & 42.10 & 0.18 & 0.89 \\
\hline
\end{tabular}

$\operatorname{Pr}>|t|$ : values $<0.05$ are statistically different. MNS: mean; SD: standard deviation. DWG: daily weight gain; DFI: daily feed intake; FCR: feed conversion ratio; BT: backfat thickness; LMA: Longissimus dorsi muscle area; LM: lean meat.

Table 4. Productive characteristics and carcass quality in male pigs with different castration techniques in the stage of $75-100 \mathrm{~kg} \mathrm{BW}$

\begin{tabular}{|c|c|c|c|c|c|}
\hline \multirow{2}{*}{ Variable } & \multicolumn{2}{|c|}{ Surgical castration } & \multicolumn{2}{|c|}{ Immunocastration } & \multirow{2}{*}{$\mathrm{p}$ Value } \\
\hline & MNS & SD & MNS & SD & \\
\hline DWG $\left(\mathrm{kg} \mathrm{d}^{-1}\right)$ & 0.92 & 0.46 & 1.01 & 0.47 & 0.52 \\
\hline $\mathrm{DFI}\left(\mathrm{kg} \mathrm{d}^{-1}\right)$ & 3.52 & 0.98 & 3.44 & 0.70 & 0.81 \\
\hline $\mathrm{FC}(\mathrm{kg} / \mathrm{kg})$ & 4.69 & 2.68 & 3.97 & 1.78 & 0.43 \\
\hline $\mathrm{BT}(\mathrm{mm})$ & 8.28 & 2.67 & 7.24 & 1.55 & 0.47 \\
\hline LMA $\left(\mathrm{cm}^{2}\right)$ & 43.72 & 8.61 & 44.64 & 7.41 & 0.86 \\
\hline LM (\%) & 41.92 & 2.85 & 42.32 & 2.68 & 0.82 \\
\hline
\end{tabular}

Pr $>|t|$ : values < 0.05 are statistically different. MNS: mean; SD: standard deviation. DWG: daily weight gain; DFI: daily feed intake; FCR: feed conversion ratio; BT: backfat thickness; LMA: Longissimus dorsi muscle area; LM: lean meat.

Dalla Costa et al. (2020), found that immunocastration improved DWG, FLW and FC ( $P<0.008)$, which also improved the reduction of DF $(P<0.0001)$ and increased \%LM ( $P<0.0001)$ in the ICM carcasses, because the androgenic hormones produced by the testicles in the second dose promote a redistribution of nutrients to favor the synthesis of muscular and bone tissue, and consequently the adipose tissue is reduced compared to surgically castrated pigs (Boler et al., 2011).
On the contrary, Daza et al. (2016) did not observe differences in BT and LMA due to the type of castration, results that are similar to this study since differences were not obtained ( $p>0.05)$ between BT, LMA and $\%$ LM treatments. However, although there were no differences in the present study, in the treatment of ICM the values of LMA were higher and the BT lower in the three stages compared to SCM (Table 2, 3 and 4); in the first stage (25-50 kg BW) there was a higher \%LM in ICM, from the second application of the vaccine and the behavior of this variable is very similar to those of the SCM. These results are similar to those by Fábrega et al. (2010), who observed that the ICM presented higher LMA compared to the SCM.

\section{Physicochemical Variables of the Meat}

Table 5 shows that the values obtained in $\mathrm{pH}, \mathrm{WHC}$ and color did not show differences ( $P>0.05$ ) between treatments, which is similar to that reported by Fernandes et al. (2017). Zamaratskaia and Krøyer (2015) point out that the parameters of meat quality and of meat in general differ between ICM and SCM, similar results to those obtained in this study.

Braña et al. (2011) describe that the WHC is influenced by the muscle's $\mathrm{pH}$. The further away the $\mathrm{pH}$ is from the isoelectric point (5.0-5.5) of meat proteins, the more water they retain. Considering this affirmation, the fact that there is not difference in the WHC between the treatments can be because the $\mathrm{pH}$ is also similar between both treatments.

In addition to the $\mathrm{pH}$, there are other factors that affect WHC, among them the race, the type 
of fiber, the oxidative stability of their membranes, the maturation process, and if the case may be, the system used to freeze and thaw the meats (Braña et al., 2011).

\section{CONCLUSIONS}

Immunocastration does not affect the productive parameters, carcass quality, or physicochemical characteristics of the pork meat compared with surgical castration, which is why the first is an alternative to surgical castration, since this technique produces less stress in the pig and is more in accordance to animal welfare, in addition to immunocastration demanding less time invested.

\section{REFERENCES}

Batorek, N., Škrlep, M., Prunier, A., Louveau, I., Noblet, J., Bonneau, M., \& Čandek-Potokar, M. (2012). Effect of feed restriction on hormones, performance, carcass traits, and meat quality in immunocastrated pigs. Jounal of Animal Science, 90(12) 4593-4603. https://doi.org/ 10.2527/jas.2012-5330.

Boler, D.D., Kutzler, L.W., Meeuwse, D.M., King, V.L., Campion, D.R. McKeith, F.K., \& Killefer, J. (2011). Effects of increasing lysine on carcass composition and cutting yields of immunologically castrated male pigs. Journal of Animal Sicence, 89(7), 21892199. DOI: 10.2527/jas.2010-3640

Braña, V.D., Ramírez, R. E., Rubio, L.M.S., Sánchez, E.A., Torrescano, U.A., Arenas, M. M.L., Partida, de la P., J.A., Ponce, A.E. y Ríos, R.F.G. (2011). Manual de Análisis de Calidad en Muestras de Carne. Centro Nacional de Investigación Disciplinaria en Fisiología y Mejoramiento Animal. 91 p.

Clarke, I., Wlaker, J., Hennessy, D., Kreeger J., Nappier, J., \& Crane, J. (2008). Inherent food safety of a sinthetic gonadotropinreleasing factor (GnRF) vaccine for the control of boar taint in entire male pigs. International Journal of Applied Research in Veterinary Medicine, 6(1), 7-14

Claus, R., Lacorn, M., Danowski, K., Pearce, M.C., \& Bauer, A. (2007) Short-term endocrine and metabolic reactions before an after second immunization against $\mathrm{GnRH}$ in boars. Vaccine, (25) 489-4696

Dalla Costa O.A., Tavernari, F.C., Lopes, L.S., Dalla Costa, F.A., Feddern, V. \& De Lima G. J.MM. (2020). Performance carcass and meat quality of pigs submitted to immunocastration and different feedeng programs. Research in Veterinary Science, 131, 137-145.

Daza, A., Latorre, M.A., Olivares, A., \& López B.C.J. (2016). The effects of male and female immunocastration on growth performances and carcass and meat quality of pigs intended for dry-cured ham production: A preliminary study. Livestock Sience, 190, 20-26.

Dunshea, F.R., Allison, J.R.D., Bertram, M., Boler, D.D., Brossard, L. Campbell, R., Crane, J.P., Hennessy, D.P., Huber, L., De Lange, C., Ferguson, N., Matzat, P., Mckeith, F., Moraes, P.J.U., Mullan.
B.P., Noblet, J., Quiniou, N., \& Tokach, M. (2013). The effect of immunization against GnRF on nutrient requirements of male pigs: A review. Animal, 7, 1769-1778.

Fàbrega, E., Velarde, A., Cros, J., Gispert, M., Suárez, P., Tibau, Jb, \& Soler, J. (2010). Effect of vaccination against gonadotrophinreleasing hormone, using Improvac ${ }^{\circledR}$, on growth performance, body composition, behaviour and acute phase proteins Livestock Science, 132, 53-59

Fernandes, A.R., de Pena, M.S., do Carmo, M.A., Coutinho, G.A., \& Benevenuto, A.A., Jr. (2017). Performance, carcass characteristics and meat quality of pigs under surgical or immunological castration. Revista Brasileira de Saude e Producao Animal, 18(2): 303-312

Grela, E. R., Świątkiewicz, M., Kowalczuk, V.E., Florekc, M., Kosior K.U., \& Skałeckic, P. (2020). An attempt of implementation of immunocastration in swine production-impact on meat physicochemical quality and boar taint compound concentration in the meat of two native pig breeds. Livestock Science, 232, 103905. DOl:10.1016/j.livsci.2019.103905

Guerreo, L.I., Pérez, C. M. L. y Ponce, A. E. (2002), Curso práctico de tecnología de carnes y pescado. Universidad Metropolitana, Unidad Iztapalapa. D.F. México

Instituto Nacional de Estadística, Geografía e Informática (INEGI). 1993. Aspectos Geográficos. In: Tulancingo de Bravo Estado de Hidalgo Cuaderno Estadístico Municipal. INEGI. México. pp $3-5$

McGlone, J.J., Nicholson, R.I., Hellman, J.M., \& Herzog, D.N. (1993). The development of pain in young pigs associated with castration and attempts to prevent castration-induced behavioral changes. Journal Animal Science, 71, 1441-1446.

Morales, J.I., Serrano, M.P., Cámara, L., Berrocoso, J.D., López, J.P. \& Mateos, G.G. (2013). Growth performance and carcass quality of immunocastrated and surgically castrated pigs from crossbreds from Duroc and Pietrain sires. Journal of Animal Science, 91(8), 3955-3964

National Pork Producers Council (NPPC). 1991. Procedures to evaluate market hogs. National Pork Producers Council. Des Moines IA, USA. p: 16

National Research Council (NRC). (2012). Nutrient requirements tables and feed ingredient composition. Nutrient Requirements of swine 11th. National Academy Press, Washintong, D.C. pp 208-239 
Oonk, H. B., Turkstra, J.A., Shcaaper, W.M.M, Erkens, J. H.F., Schuitermaker-de Weerd, M.H., van Nes, A., Verheijden, J.H.M., \& Meloen, R.H. (1998). New GnRH-like peptide construct to optimize efficient immunocastration of male pigs by immunoneutralization of $\mathrm{GnRH}$. Vaccine, 16, 1074-1082

Poulsen Nautrup, B., Van Vlaenderen, I., Aldaz, A., \& Mah C.K. (2018). The effect of immunization against gonadotropin-releasing factor on growth performance, carcass characteristics and boar taint relevant to pig producers and the pork packing industry: A meta-analysis. Research in Veterinary Science, 119, 182-195.

Quiles, A. 2005. Castración de lechones: Ventajas e inconvenientes. Revista Cría y Salud, 24, $54-62$

Runier, A., Mounier, A.M., \& Hay, M. (2005). Effects of castration, tooth resection, or tail docking on plasma metabolites and stress hormones in young pigs. Journal of Animal Science, $83,216-222$

Secretaría de Gobernación (SEGOB). (2015). Diario Oficial de la Federación: Norma Oficial Mexicana NOM-033-SAG/ZOO-2014, Métodos para dar muerte a los animales domésticos y silvestres.

Statistical Analysis System (SAS). (2010). The SAS system for Windows V8. SAS 9.3. Institute, Cary, N.C. USA.

Zamaratskaia, G., \& Krøyer, R. G. (2015). Immunocastration of male pigs-situation today. Procedia Food Sience, (5) 324-327. 